\title{
THE FUTURE OF COMPULSORY DisPUTE SETTLEMENT UNDER THE LAW OF THE SEA CONVENTION
}

\author{
Rosemary Rayfuse
}

\begin{abstract}
In this article Rosemary Rayfuse evaluates the dispute resolution provisions found in Part XV of the United Nations Law of the Sea Convention (UNCLOS). While the cases emerging from the International Tribunal on the Law of the Sea (ITLOS) to date have been limited in number, they can provide us with some idea of whether the Part XV machinery has been successful, and allow some predictions to be made as to its continuing role in the development of the law of the sea. Having examined this jurisprudence, she concludes that while the fears of fragmentation in the sense of inconsistent interpretations or applications of legal rules have not yet materialised, the overall role for the dispute settlement provisions in the development of international law seems rather limited.
\end{abstract}

\section{INTRODUCTION}

Heralding in a new era in international law, the United Nations Convention on the Law of the Sea (UNCLOS) ${ }^{1}$ introduced what was considered to be an innovative and far-reaching compulsory dispute settlement system. ${ }^{2}$ Seen as part of the "package deal" of the UNCLOS, the dispute settlement provisions contained in Part XV were viewed as necessary to balance the interests of all states against the increased jurisdictional competences given to coastal states by the Convention. In addition to providing for compulsory recourse to a range of extant procedures including conciliation, arbitration and the International Court of Justice (ICJ), the LOSC also provided for the establishment of a new standing international court, the International Tribunal for the Law of the Sea (ITLOS) and its specialist Sea-Bed Disputes Chamber.

* Associate Professor, Faculty of Law, University of New South Wales.

1 United Nations Convention on the Law of the Sea (10 December 1982) 1833 UNTS 3.

2 Tommy T B Koh "A Constitution for the Oceans" Remarks made by the President of the Third United Nations Conference on the Law of the Sea, in Official Text of the United Nations Convention on the Law of the Sea with Annexes and Index (1983) E 83V5, xxxiii. 
The compulsory dispute settlement provisions of Part XV have been heavily criticised as contributing to the potential fragmentation, both procedurally and substantively, of the law of the sea and of international law in general. Only ten years after the coming into force of the UNCLOS,${ }^{3}$ and eight years since the establishment of ITLOS, ${ }^{4}$ it is undoubtedly premature to definitively assess the contribution to international law of the provisions. Nevertheless, sufficient practice and jurisprudence has emerged to allow a preliminary assessment of the efficacy of the provisions to be made, and to provide a tentative prognosis as to the future of compulsory dispute settlement under UNCLOS.

This paper begins with a brief overview of the Part XV compulsory dispute settlement provisions. It then sets out the various criticisms that have been levelled against the provisions. It then analyses whether, in light of subsequent jurisprudence, those criticisms have thus far proved justified or ill-founded. The implications of this jurisprudence for the future of compulsory dispute settlement under UNCLOS are then assessed. Arguably, any assessment of the present and future of the compulsory dispute provisions will depend on differing appreciations and interpretations as to the form, function, and role of both UNCLOS and its relationship with other treaties, and that of compulsory dispute settlement in the development of UNCLOS and the broader rule of international law in general. ${ }^{5}$ It will be demonstrated that, while reports of the death of Part XV may be premature, it remains to be seen whether, on even a narrow understanding of its perceived promise of compulsory dispute settlement in the law of the sea, that promise will be achieved.

\section{THE UNCLOS COMPULSORY DISPUTE SETTLEMENT REGIME}

Part XV deals with the settlement of disputes concerning the interpretation or application of UNCLOS. ${ }^{6}$ The first section of Part XV begins with a recitation of the general obligation on states to settle their disputes by agreement and to do so peacefully. ${ }^{7}$ It preserves the right for states to agree at any time to settle their disputes by a means of their choice, in which case, the dispute is

3 UNCLOS came into force on 16 November 1994

4 ITLOS was formally inaugurated on 18 October 1996. It heard its first case in November 1997.

5 B Oxman "Complementary Agreements and Compulsory Jurisdiction" (2001) 95 AJIL 277.

6 For more detailed discussion see R Churchill and V Lowe The Law of the Sea (2 ed, Manchester University Press, Manchester, 1999) 453-459; A Odede "The Basic Structure of the Dispute Settlement Part of the Law of the Sea Convention" (1982) 11 Ocean Dev and Int'l Law 125; M Gaertner "The Dispute Settlement Provisions of the Convention on the Law of the Sea: Critiques and Alternatives to the International Tribunal for the Law of the Sea" (1982) 19 San Diego L Rev 577; J W Kindt "Dispute Settlement in International Environmental Issues: The Model Provided by the 1982 Convention on the Law of the Sea" (1989) Vand J of Transnat'l L 1097; J K Gamble "The 1982 UN Convention on the Law of the Sea: Binding Dispute Settlement?" (1991) 9 BU Int'l LJ 39; T Treves "Dispute Settlement Clauses in the Law of the Sea Convention and their Impact on the Protection of the Marine Environment: Some Observations" (1999) 8 RECIEL 6.

$7 \quad$ United Nations Convention on the Law of the Sea, above n 1, art 279. 
exempt from the Part XV procedures except where no settlement has been reached and the agreement does not exclude any further procedure. ${ }^{8}$ Dispute settlement procedures in other general, regional or bilateral agreements which entail binding decisions are to apply in lieu of the Part XV procedures. ${ }^{9}$ In all cases, when disputes arise states are to expeditiously exchange views regarding their settlement and may elect to proceed to voluntary conciliation. ${ }^{10}$

Where, however, states have been unable to peacefully resolve their disputes and no other procedure for resolution of the dispute has otherwise been agreed upon then, under Section 2 of Part XV, they are obliged to submit their dispute to either the International Tribunal for the Law of the Sea, the International Court of Justice, an Arbitral Tribunal established pursuant to Annex VII or a special Arbitral Tribunal established pursuant to Annex VIII. The choice of tribunal will depend on prior declarations made by the parties, and when no common choice is agreed then Annex VII arbitration is the default position. ${ }^{11}$ In other words an Annex VII arbitral tribunal is the norm unless states have agreed otherwise. The court or tribunal so chosen has jurisdiction over any dispute concerning the interpretation or application of UNCLOS, or of any other international agreement related to the purposes of UNCLOS where the parties so agree, subject to a number of exceptions set out in Section 3 of Part XV. ${ }^{12}$ Broadly speaking, these exceptions relate to the exercise by coastal states of their sovereign rights within the exclusive economic zone (EEZ) relating to conservation and management of living resources and the conduct of marine scientific research. ${ }^{13}$ States are also at liberty to make declarations exempting disputes relating to maritime boundary delimitation, historic bays or titles, military activities, law enforcement activities, or disputes in respect of which the United Nations Security Council is exercising its functions, from the compulsory regime. ${ }^{14}$

8 United Nations Convention on the Law of the Sea, above n 1, arts 280 and 281.

9 United Nations Convention on the Law of the Sea, above n 1, art 282.

10 United Nations Convention on the Law of the Sea, above n 1, arts 283 and 284. Disputes relating to the area are to be submitted only to the Sea-Bed Disputes Chamber of ITLOS pursuant to Part XI (Art 287(2)) While they, too, are subject to compulsory settlement procedures those procedures are found in Part XI of UNCLOS and not Part XV and are therefore beyond the scope of this paper. For an extensive analysis see N J Seeberg-Elverfeldt The Settlement of Disputes in Deep Seabed Mining (Nomos Verlagsgesellschaft, Baden-Baden, 1998).

11 United Nations Convention on the Law of the Sea, above n 1, arts 286 and 287.

12 United Nations Convention on the Law of the Sea, above n 1, art 288

13 United Nations Convention on the Law of the Sea, above n 1, art 297.

14 United Nations Convention on the Law of the Sea, above n 1, art 298. 


\section{CRITICISMS OF THE UNCLOS COMPULSORY DISPUTE SETTLEMENT REGIME}

In the lead up to the entry into force of UNCLOS, its compulsory dispute settlement provisions were the subject of heavy criticism. ${ }^{15}$ It was pointed out that the limitations and exclusions in Part $\mathrm{XV}$ would ensure that a broad range of ocean disputes would not be subject to the compulsory procedures at all. ${ }^{16}$ Indeed, the only disputes to which compulsory settlement procedures might definitely apply are those relating to alleged contraventions of the high seas freedoms of fishing, navigation, overflight, laying of submarine cables and pipelines, or other internationally lawful uses of the sea in the exclusive economic zone, and disputes relating to the contravention by coastal states of specified international rules and standards for the protection or preservation of the marine environment.

Criticism was also directed at the provisions for the establishment, and selection, of a wide range of tribunals on the basis that each tribunal listed would clearly have different functions and there was no way to ensure that their procedures and modus operandi would be appropriate to the dispute before them. Several judges of the International Court of Justice, in particular, warned that the creation of a plethora of tribunals could only lead to fragmentation of international law and the law of the sea due to the emergence of competing interpretations in a non-uniform manner from inconsistent decisions of the different tribunals, each having a different jurisdictional scope and expertise. ${ }^{17}$ Some of the most strident criticism was directed towards the proposed ITLOS which these judges saw as a judicial competitor to the ICJ and an unnecessary and unhelpful addition to the proliferation of international tribunals. Self-serving machinations of ICJ judges aside, there

15 See for example Shigeru Oda "The International Court of Justice Viewed from the Bench" (1993) 244 Recueil des Cours 127; Shigeru Oda "Dispute Settlement Prospects in the Law of the Sea" (1995) 44 ICLQ 863 ["Dispute Settlement Prospects in the Law of the Sea"]; Shigeru Oda "Some Reflections on the Dispute Settlement Clauses in the United Nations Convention on the Law of the Sea" in J Maraczk Essays in International Law in Honour of Judge Manfred Lachs (Martinus Nihoff, Zoetermeer (The Netherlands), 1984) ["Some Reflections on the Dispute Settlement Clauses in the United Nations Convention on the Law of the Sea"]. See also G Guillaume "The Future of International Judicial Institutions" (1995) 44 ICLQ 848; and Elihu Lauterpacht Aspects of the Administration of International Justice (Cambridge University Press, Cambridge, 1991) 20-22.

16 "Dispute Settlement Prospects in the Law of the Sea", above n 15, 866-871; and "Some Reflections on the Dispute Settlement Clauses in the United Nations Convention on the Law of the Sea", above n 15, 653-655.

17 See for example Judge Stephen M Schwebel, President of the International Court of Justice (Address to the United Nations General Assembly, 26 October 1999); Judge Gilbert Guillaume, President of the International Court of Justice (Address to the United Nations General Assembly, 26 October 2000). Both texts available at $<$ http://www.icj-cij.org/icjwww/ipresscom/iprstats/htm>. 
was a particular concern that ITLOS would corner the market on law of the sea jurisprudence, separating it from, and thereby undermining, the wider context of international law in general. ${ }^{18}$

Fears about the proliferation of tribunals have not been shared by other commentators. In 1997, Boyle analysed how far the fears of fragmentation and the potentially adverse role of ITLOS were justified concluding, with respect to the possible adverse implications of the proliferation of tribunals, that it was still "too early to assess how far competition between different international tribunals [would] promote the settlement of disputes, or whether it [would] fragment either the substantive law of the sea or international law in general". ${ }^{19}$ Others have likewise evidenced concern that certain disputes were excluded from Part XV, but have considered this the price of compromise which should not be seen as a fault but rather as an indication of the exceptional nature of UNCLOS regime. ${ }^{20}$ Indeed, a vast body of literature has been spawned which extols the virtues of the positive contribution of Part XV in general, and ITLOS in particular, to the development of the law of the sea and international law more broadly. ${ }^{21}$ Less easy to counter, however, have been concerns that the categorisation and separation of different elements of a dispute, some of which will lead to binding compulsory settlement while others will not, would inexorably undermine the Part XV regime and lead to further fragmentation into compulsory and consensual forms of jurisdiction - with more emphasis being placed on the latter. ${ }^{22}$

Essentially, what has worried commentators is the possibility for both substantive and procedural fragmentation of the law of the sea. This situation is not unique to the law of the sea

18 See for example "Dispute Settlement Prospects in the Law of the Sea", above n 15, 864; Guillaume, above n 15, 848

19 A Boyle, "Dispute Settlement and the Law of the Sea Convention: Problems of Fragmentation and Jurisdiction" (1997) 46 ICLQ 37, 41.

20 See for example J Charney "Is International Law Threatened by Multiple International Tribunals?" (1998) 271 Recueil des Cours 101; J Charney "The Impact of the International Legal System of the Growth of International Courts and Tribunals" (1999) 31 NYU J Int'l L and Pol 697; PM Dupuy "The Danger of Fragmentation or Unification of the International Legal System and the International Court of Justice" (1999) 31 NYU J Int'l L and Pol 791; G Abi-Saab, "Fragmentation or Unification: Some Concluding Remarks" (1999) 31 NYU J Int'l L and Pol 919; and M Koskenniemi and P Leino, "Fragmentation in International Law? Postmodern Anxieties" (2002) 15 Leiden Journal of International Law 553.

21 See for example the essays collected in N Ando and others (eds) Liber Amicorum Judge Shigeru Oda (Kluwer, The Hague, 2002); and in P Chandresekhara Rao and R Kahn (eds) The International Tribunal for the Law of the Sea: Law and Practice (Kluwer, The Hague, 2002); I Shearer "The ITLOS and its Potential for Resolving Navigation Disputes" in D Rothwell and S Bateman (eds) Navigational Rights and Freedoms and the New Law of the Sea (Kluwer, The Hague, 2000); D Rothwell "The International Tribunal for the Law of the Sea and Marine Environmental Protection: Expanding the Horizons of International Oceans Governance" (2003) 17 Ocean Yearbook 26; and D Rothwell "Building on the Strengths and Addressing the Challenges: The Role of Law of the Sea Institutions" (2004) 35 Ocean Dev and Int'l Law 131.

22 Boyle, above n 19, 41. 
but has been identified by the International Law Commission (ILC) as posing potentially significant difficulties to international law in general. ${ }^{23}$ While many interpretations of the terminology exist, for the purposes of this article, substantive fragmentation relates to the issue of consistency and continuity in the development and application of legal principles, while procedural fragmentation relates to the issue of the availability and appropriateness of the dispute settlement forum. Although in many respects the two types of fragmentation are separate and distinct they are also fundamentally intertwined, in that choice of forum may have implications for the characterisation of a dispute, and vice versa, which will in turn have implications for the substantive resolution of the dispute.

The following section examines the Part XV jurisprudence to date in an attempt to determine whether, and if so to what extent, the feared substantive and procedural fragmentation has occurred. The paper then turns to an analysis of the implications of the jurisprudence for the future of compulsory dispute settlement under UNCLOS.

\section{PRACTICE PURSUANT TO THE UNCLOS COMPULSORY DISPUTE SETTLEMENT REGIME}

\section{A Part XV and Substantive Fragmentation}

Although it may seem a tedious affair, to assess the existence of substantive fragmentation it is first necessary to identify the legal principles which have been invoked in the Part XV jurisprudence. In this respect it must be noted that the bulk of the - admittedly limited jurisprudence to date has related to procedures for the prompt release of vessels and requests for provisional measures within ITLOS, as well as with the jurisdictional phases of disputes. Only one dispute has thus far been determined on its merits. Within this jurisprudence, however, a number of legal rules have been discussed and/or developed including: rules relating to the admissibility of claims; rules relating to the determination of a reasonable bond for the purposes of prompt release applications; rules relating to the prescription of provisional measures; and other substantive rules such as those relating to nationality of ships and the extent of coastal state rights within the EEZ.

23 The topic of "risks ensuing from fragmentation of international law" was identified by the ILC in 1999 as one suitable for study. After consideration of a feasibility study the topic was placed on the ILC's programme in 2002. A Study Group on the Fragmentation of International Law was established in 2002 and the topic has been considered annually by the Commission since. See UNGA "Report of the $55^{\text {th }}$ Session of the International Law Commission" (2003) A/57/10, ch 10; ILC "Draft Report of the $56^{\text {th }}$ Session of the International Law Commission (4 August 2004) A/CN.4/L.659; see also ILC "Report of the Study Group on Fragmentation of International Law: Difficulties arising from the Diversification and Expansion of International Law" (18 July 2003) A/CN.4/L.644; ILC "Report of the Study Group on Fragmentation of International Law: Difficulties arising from the Diversification and Expansion of International Law" (28 July 2004) A/CN.4/L.633/Rev.1; ILC "Report of the Chairman of the Working Group, M Koskenniemi" (2004) ILC(LVI)/SG/FIL/CRD1 and Add.1. 


\section{Rules relating to admissibility of claims}

One of the first questions to be addressed by ITLOS was the standard of proof in prompt release proceedings brought pursuant to article 292 of UNCLOS. In its first case, the MV Saiga (No 1), ${ }^{24}$ ITLOS held that given the accelerated and independent nature of prompt release proceedings it was sufficient only to note that breaches of article 73(2) of UNCLOS relating to prompt release had been alleged and that the allegations were arguable or of a sufficiently plausible character that they could be relied on for the purposes of the prompt release proceedings. The allegations did not need to be proved. Neither would ITLOS or any other tribunal be bound by the characterisation of the allegations should the case proceed on the merits. ${ }^{25}$ In other words, the benefit of the doubt was to be given to the applicant without prejudice to the tribunal subsequently changing its mind. This was particularly prescient in this case as ITLOS did, in fact, appear to change its mind on the legal characterisation of bunkering in the EEZ at the later merits stage. For present purposes, however, according to Rosenne, granting the benefit of doubt to the applicant in such cases is consistent with the "wide practice of international courts and tribunals" 26 so this, in itself, is not evidence of substantive fragmentation.

With respect to limitation periods, in the Camouco case the Tribunal found that a delay of more than three months in the bringing of the prompt release application was not fatal and did not give rise to an estoppel. ${ }^{27}$ Article 292 merely required prompt release once an application had been brought, not the prompt bringing of an application. ${ }^{28}$ Given the specific wording of article 292 this result has been considered consistent with principle. ${ }^{29}$

ITLOS has also had occasion to deal with the domestic remedies rule. In the MV Saiga (No 2) case the Tribunal found that it was the rights of Saint Vincent and the Grenadines vis-à-vis its national (the vessel) which had been directly violated, not the rights of any alien individuals. ${ }^{30}$ Moreover, in order for the rule to apply, there had to exist a "jurisdictional connection between the person suffering damage and the state responsible for the wrongful act which caused the

24 MV Saiga (No 1) (St Vincent v Guinea) (1998) 37 ILM 360 (ITLOS).

25 MV Saiga (No 1), above n 24, paras 50-51 and 59.

26 S Rosenne "International Tribunal for the Law of the Sea: 1996-97 Survey" (1998) 13 Int'l J Marine and Coastal L 487, 513 [Survey for 1996-97]. See also, B Kwiatkowska "The Saint Vincent and the Grenadines v Guinea M/V Saiga Cases before the International Tribunal for the Law of the Sea" in D Rothwell and S Bateman (eds) Navigational Rights and Freedoms and the New Law of the Sea (Kluwer, The Hague, 2000).

27 Camouco (Panama v France) (2000) 39 ILM 666 (ITLOS).

28 Camouco, above n 27, para 54.

29 V Lowe "The International Tribunal for the Law of the Sea: Survey for 2000" (2001) 16 Int'l J Marine and Coastal L 549, 556 [Survey for 2000].

30 MV Saiga (No 2) (St Vincent v Guinea) (1999) 38 ILM 1323 (ITLOS). 
damage". ${ }^{31}$ Since Guinea was not entitled under UNCLOS to exercise its customs laws in the manner it had, there could be no jurisdictional nexus between it and any individual against whom the unlawful acts had been taken and therefore no domestic remedies to be exhausted. Likewise, in the Camouco case, the Tribunal held that any alleged failure to have exhausted domestic remedies was irrelevant. Article 292 provided an independent remedy separate from domestic remedies which could be exercisable at any time and limitations which sought to defeat the object and purpose of the article should not be read into it. ${ }^{32}$ These results may be consistent with prior international jurisprudence and principle. However, the Tribunal's application of the domestic remedies rule has been heavily criticised on the basis that it leads to fragmentation caused by the complications arising from parallel proceedings in national and international tribunals and simply encourages "forum-hopping". ${ }^{33}$

\section{Rules relating to determination of reasonable bond}

Arguably, ITLOS jurisprudence relating to the assessment of a reasonable bond for the purposes of article 73 of UNCLOS cannot provide evidence of substantive fragmentation in the sense of inconsistent application as between various tribunals because this jurisprudence is, to date, unique to ITLOS, although in theory prompt release proceedings can be brought by agreement before other courts or tribunals as agreed between the parties. ${ }^{34}$ This is not to suggest, however, that its delineation of criteria has been uncontentious. On the contrary, the large number of dissenting and separate opinions show the issue has been, and continues to be, problematic.

In MV Saiga (No 1), ITLOS held that where the detaining state had itself refused to set or accept a bond then the requesting state could not be held responsible for the fact that no bond had been posted. Indeed, article 73(2) could be infringed even where no bond had been posted. As to the sufficiency of bond, ITLOS noted that it had to be of more than mere "symbolic" value but must be reasonable in both nature and form. ${ }^{35}$ In the Camuoco case ITLOS again rejected the argument that there could be no breach of the duty to release upon posting of a reasonable bond unless the bond had actually been posted. The only question was whether the bond which had been set by the domestic French courts was reasonable. This time ITLOS enunciated a number of factors which it considered relevant to the assessment of reasonableness of bonds including the gravity of the alleged offences, the penalties imposed or imposable under the laws of the detaining state, the value of the detained vessel and of the cargo seized, the amount of bond imposed by the detaining

31 MV Saiga (No 2), above n 30, para 99.

32 Camouco, above n 27, paras 57-58.

33 See Camouco, above n 27, Dissenting opinion of Judges Anderson and Lowe; Survey for 2000, above n 29 , 557-558.

34 United Nations Convention on the Law of the Sea, above n 1, art 292.

35 M/V Saiga (No 1), above n 24, paras 78-82. 
state, and its form. ${ }^{36}$ ITLOS also considered the issue of detention of the master, finding that although he was not in custody, court supervision and the confiscation of his passport constituted detention from which he was to be released under article $292 .{ }^{37}$

In discussing the preliminary issue of admissibility in Cатиосо ITLOS had noted that the object and purpose of article 292 was, on the one hand: ${ }^{38}$

... to free a ship and its crew from prolonged detention on account of the imposition of unreasonable bonds in municipal jurisdictions, or the failure of local law to provide for release on posting of a reasonable bond, inflicting thereby avoidable loss on a ship owner or other persons affected by such detention

And, on the other, to: 39

... safeguard the interests of the coastal State by providing for release only upon the posting of a reasonable bond or other financial security determined by a court or tribunal referred to in article 292, without prejudice to the merits of the case in the domestic forum against the vessel, its owner or its crew.

Implicit in this discussion, appears to have been ITLOS's belief that reasonableness should be assessed in the overall framework of this object and purpose.

This approach was made explicit in the Monte Confurco case, ${ }^{40}$ ITLOS noting that the balance between the two interests was a fair one which must provide the guiding criteria for the assessment of reasonableness. Adding a gloss on its earlier decision, however, ITLOS also noted that it would treat the laws of the detaining state and the decisions of its courts as relevant facts in assessing reasonableness. ${ }^{41}$ Reiterating its Camouco test, ITLOS then went on to clarify that the factors earlier identified were not a complete list and no rigid determination of the weight to be accorded to each could be given. ${ }^{42}$

This test was also applied in the Volga case where it was further held that the "bond or other security" referred to in article 73 must be of a financial nature. ${ }^{43}$ The imposition of other nonfinancial requirements such as a requirement that the vessel carry a fully operational vessel monitoring system upon release, or a requirement that the information concerning the owner and

\footnotetext{
36 Camouco, above n 27, para 67.

37 Camouco, above n 27 , para 71

38 Camouco, above n 27, para 57

39 Camuoco, above n 27 , para 57.

40 Monte Confurco (Seychelles v France) [2002] ITLOS 2.

41 Monte Confurco, above n 40, paras 70-72.

42 Monte Confurco, above n 40, para 76.

43 Volga (Russia v Australia), (2002) 42 ILM 159 (ITLOS)
} 
ultimate beneficial owners of the vessel be submitted to the detaining state's authorities, or other "good behaviour bond", could not constitute a bond or security within the meaning of article 73 and was therefore unreasonable. On the other hand, while it might be relevant to later proceedings, the legality or otherwise of the seizure of the vessel was not to be taken into account in assessing reasonableness of the bond. ${ }^{44}$

While the delineation of these factors may appear, at first blush, to be reasonable and consistent with broader legal principle, it must be noted that in both the Camuoco and the Volga cases the respondents had argued that ITLOS ought to take into account the wider picture of international concern regarding the deleterious effects of illegal fishing on both regional and domestic regimes aimed at securing the sustainable management of marine resources. Although it accepted the relevance of domestic penalties to the evaluation of the gravity of the offence, ITLOS did not accept that this wider concern with conservation and management of marine living resources was relevant in the prompt release context. This decision was criticised by dissenting Judge ad hoc Shearer who felt that more regard should have been had to the problem of illegal fishing and the difficulty of enforcement, particularly in the inhospitable Southern Ocean, and particularly given that both Russia and Australia were members of the Commission on the Conservation of Antarctic Marine Living Resources, in contravention of whose measures, as applied in the Australian EEZ, the Volga had been fishing. According to Judge ad hoc Shearer, it was time for ITLOS to establish a "new 'balance' between vessel owners, operators and fishing companies on the one hand, and coastal states on the other". 45

While accepting the appropriateness of a narrowly circumscribed prompt release jurisdiction, commentators have nevertheless noted the worrying implications of these decisions for the interpretation and application of UNCLOS duties relating to conservation and management of marine living resources. ${ }^{46}$ Indeed, far from balancing the interests of coastal and fishing states, the decisions appear to drain the essence right out of the duty to cooperate in conservation and management of marine living resources and shift the balance in favour of the flag state. This flies in the face of over a decade of serious exertions on the part of the international community to give meaning to the duty to cooperate, as evidenced by the negotiation of the United Nations Fish

44 Volga, above n 43, 72-80.

45 Volga, above n 43, Dissenting Opinion of Judge ad hoc Shearer, paras 10 and 19.

46 D Rothwell and T Stephens "Illegal Southern Ocean Fishing and Prompt Release: Balancing Coastal and Flag State Rights and Interests" (2004) 53 ICLQ 171; A Serdy and M Bliss "Prompt Release of Fishing Vessels: State Practice in the Light of the Cases before the International Tribunal for the Law of the Sea" in A G Oude Elferink and D Rothwell (eds) Oceans Management in the 21st Century: Institutional Frameworks and Responses (Martinus Nijhoff, Leiden, 2004); D Rothwell "Building on the Strengths and Addressing the Challenges: The Role of Law of the Sea Institutions" (2004) 35 Ocean Dev and Int'l L 131. 
Stocks Agreement, ${ }^{47}$ and the global fight against illegal, unregulated and unreported (IUU) fishing. Thus, even if ITLOS's own jurisprudence may demonstrate an internal consistency of development, when placed in the broader context of other principles of international law, such as those relating to the conservation and management of marine living resources or protection of the marine environment, the consistency issue becomes more troubling. While this may not provide conclusive evidence of substantive fragmentation, there are those who decry the fact that this shift in balance in favour of flag state rights should be made by UNCLOS's own tribunal. ${ }^{48}$

\section{Rules relating to the prescription of provisional measures}

Inconsistency with broader principle may also be at issue in the context of ITLOS jurisprudence relating to its jurisdiction to prescribe provisional measures. The uniqueness of this jurisprudence arises primarily from the specific provisions of UNCLOS by which this jurisdiction is exercised. Under article 290(1) a court or tribunal which considers it has prima facie jurisdiction under Part XV may prescribe provisional measures to preserve the respective rights of the parties to the dispute or to prevent serious harm to the marine environment, pending final decision. Under article 290(5) where an arbitral tribunal has not yet been constituted and the parties have failed within two weeks to agree on submission of the request to a court or tribunal then ITLOS may prescribe provisional measures if it considers, prima facie, that the tribunal which is to be constituted will have jurisdiction and that the urgency of the situation so requires. While article 290(1) reflects accepted notions of incidental jurisdiction, the residual jurisdiction provided for in article 290(5) is considered to be "a relative innovation in international practice". 49 To date, ITLOS has had the opportunity to develop its provisional measures jurisprudence in four cases; one under article 290(1) and three under article 290(5). These decisions have dealt with interpretations of the standard of appreciation relevant to a determination of prima facie jurisdiction, the obligation to exchange views pursuant to article 283, and the criteria of urgency.

In its first application, the MV Saiga (No 2) (Provisional Measures), ${ }^{50}$ ITLOS made an order for provisional measures even though technically, since the vessel had been released, the request was no longer urgent and had, in fact, become moot. In what has become a signal feature of its jurisprudence ITLOS nevertheless considered it necessary to call upon both parties to refrain from

47 Agreement for the Implementation of the Provisions of the United Nations Convention on the Law of the Sea of 10 December 1982 relating to the Conservation and Management of Straddling Fish Stocks and Highly Migratory Fish Stocks (4 August 1995) 24 ILM 1542.

48 Survey for 2000, above n 29, 560-561; W Gullett "Prompt Release Procedures and the Challenge for Fisheries Law Enforcement: The Judgment of the International Tribunal for the Law of the Sea in the 'Volga' Case (Russian Federation v Australia)" (2003) 31 Fed LR 395, 407.

49 S Rosenne "The International Tribunal for the Law of the Sea: Survey for 1999" (2000) 15 Int'l J Marine and Coastal L 442, 467 [Survey for 1999].

50 M/V Saiga (No2) (St Vincent v Guinea) (Provisional Measures) (11 March 1998) ITLOS order. 
doing anything to aggravate or extend the dispute and required Guinea to refrain from taking or enforcing any judicial or administrative action against the vessel or the master and crew, its owner and operators, pending determination of the merits of the case. The order in this case was criticised as going beyond both what the parties had requested and what was necessary and relevant to the circumstances of the case..$^{51}$

In the Southern Bluefin Tuna cases, ${ }^{52}$ argument raged in the provisional measures application as to whether the Annex VII arbitral tribunal which was to be established would, in fact, have jurisdiction. Dismissing Japan's arguments that the dispute was scientific, not legal, and, in any event, arose under the Convention on the Conservation of Southern Bluefin Tuna (CCSBT) which did not provide for compulsory settlement, ITLOS accepted that the applicability of the CCSBT did not preclude the dispute also arising under UNCLOS and the consequential recourse to Part XV. The Annex VII tribunal would therefore have prima facie jurisdiction. ${ }^{53}$ Additionally, negotiations had terminated and Australia and New Zealand were therefore not obliged to exhaust amicable procedures under articles 279-285 given they had concluded that the possibilities of settlement had been exhausted. ${ }^{54}$ Moreover, since conservation of marine living resources was an element of the protection of the marine environment, even in the absence of demonstrated urgency, ITLOS considered that the parties should act with "prudence and caution" to ensure measures were taken to prevent serious harm to the stocks and to cooperate with others fishing for the stocks to ensure their optimum utilisation. ${ }^{55}$ ITLOS therefore went on to indicate measures, applicable to all parties, calling for restraint from prejudicial acts including the conduct of the contentious experimental fishing programs and calling for continued efforts at reaching a negotiated agreement on conservation and management measures as between themselves and relevant to third parties and to achieving the goal of optimum utilisation. ${ }^{56}$ This decision has been the subject of both praise and criticism. Of relevance here is the question of whether ITLOS might have taken too liberal an approach to determining the issue of prima facie jurisdiction. ${ }^{57}$

51 S Rosenne "International Tribunal for the Law of the Sea: 1998 Survey" (1999) 14 Int'l J Marine and Coastal L 453, 464-465 [Survey for 1998].

52 Southern Bluefin Tuna (New Zealand v Japan, Australia v Japan) (Provisional Measures) (1999) 38 ILM 1624 (ITLOS).

53 Southern Bluefin Tuna (Provisional Measures), above n 52, paras 48-55.

54 Southern Bluefin Tuna (Provisional Measures), above n 52, paras 56-60.

55 Southern Bluefin Tuna (Provisional Measures), above n 52, paras 77-78.

56 Southern Bluefin Tuna (Provisional Measures), above n 52, para 90.

57 For a range of opinions see: Survey for 1999, above n 49, 464-473; H Shiffman "The Southern Bluefin Tuna Case: ITLOS Hears its First Fishery Dispute" (1999) 2 J Int'l Wildlife and Policy 318; B Kwiatkowska "The Southern Bluefin Tuna (New Zealand v Japan; Australia v Japan) Cases" (2000) 15 Int'1 J Marine and Coastal L 1; M Hayashi "The Southern Bluefin Tuna Cases: Prescription of Provisional Measures by the International 
This liberal approach to determining prima facie jurisdiction was, however, even more evident in the decision on provisional measures in the MOX Plant case, ${ }^{58}$ another request heard by ITLOS pending establishment of an Annex VII tribunal. In MOX Plant, ITLOS dismissed the United Kingdom's arguments relating to jurisdiction under parallel treaties finding that while aspects of the dispute might also arise under other treaties, the dispute clearly arose squarely under UNCLOS whose dispute settlement procedures were therefore the only relevant ones. ${ }^{59}$ Also rejected was the argument that Ireland had not exchanged views regarding the dispute as required under UNCLOS article 283. Reiterating its decision in the Southern Bluefin Tuna (Provisional Measures) cases, ITLOS held that a state could not be obliged to continue with an exchange of views when it had concluded that the possibility of reaching agreement had been exhausted. ${ }^{60}$ ITLOS was not, however, convinced of any urgency and therefore declined to prescribe the requested measures.

Interestingly, this result was premised on unilateral statements made by the United Kingdom during the hearings that no transports of MOX fuel would take place before the Annex VII tribunal had been established. Given the assurances, and the short period of time between the provisional measures hearing and the date for establishment of the Annex VII tribunal, ITLOS did not consider there was any urgency to the situation. ${ }^{61}$ Instead, noting that "the duty to cooperate is a fundamental principle in the prevention of pollution of the marine environment" under both UNCLOS and customary international law, ITLOS held that "prudence and caution" required Ireland and the United Kingdom to cooperate in exchanging information about the risks or effects of the operation of the MOX Plant and ordered the parties to exchange relevant information, monitor risks and effects and devise appropriate measures to prevent marine pollution from the plant. ${ }^{62}$

Many of these issues were further addressed in the Straits of Johor case, ${ }^{63}$ another request heard pending establishment of an Annex VII tribunal. In response to Singapore's contention that neither negotiations nor an exchange of views had taken place ITLOS noted that those obligations fell equally on both parties and that where they had not been able to resolve a dispute or agree on a means to settle it then a state could not be "obliged to continue with an exchange of views when it

Tribunal for the Law of the Sea" (2000) 13 Tul Envtl LJ 361; S Marr "The Southern Bluefin Tuna Cases: The Precautionary Approach to Conservation and Management of Fish Resources" (2000) 11 Euro J Int'l L 815.

MOX Plant (Provisional Measures), above n 58, paras 52-53.

63 Case Concerning Land Reclamation by Singapore in and Around the Straits of Johor (Malaysia $v$ Singapore) (Provisional Measures), (8 October 2003) ITLOS Order [Straits of Johor]. 
concluded that this exchange could not yield a positive result". ${ }^{64}$ ITLOS also clarified its earlier ruling as to the relevance of the time period between the provisional measures application and the constitution of the Annex VII tribunal in determining the question of urgency, holding that that period was not determinative. Rather, the urgency of the situation was to be assessed in the context of the broader period during which the tribunal, although constituted, would not yet be sitting or otherwise able to modify, revoke, or affirm the measures. ${ }^{65}$ Nevertheless, Singapore's land reclamation works were not likely to cause irreversible damage to Malaysia's rights in its territorial sea pending consideration of the merits of the case by the Annex VII tribunal. There was, accordingly, no urgency and ITLOS declined to award the measures requested. It did, however, make a point of "placing on record" a number of assurances and commitments made by Singapore to engage in joint studies and negotiations and to refrain from taking irreversible action pending completion of the study. It also reiterated the duty to cooperate in the protection of the marine environment. Given the possible adverse consequences for that environment of the land reclamation projects ITLOS held, once again, that "prudence and caution" required the parties to establish mechanisms for exchanging information on and assessing the effects of the land reclamation work and prescribed provisional measures to give effect to this. ${ }^{66}$

On the one hand, it is arguable that the invocation by ITLOS of its provisional measures jurisdiction is consistent with that of other international tribunals. In fact, ITLOS has specifically invoked the jurisprudence of the ICJ in determining the existence of a dispute and the extent of the obligation to negotiate. ${ }^{67}$ Interestingly, the ITLOS decisions have also evidenced an increasing adoption of unilateral statements made by parties to the dispute as the basis upon which provisional measures which had not been requested by the parties are prescribed. This appears to be consistent with the jurisprudence and practice of the ICJ in respect of unilateral declarations. ${ }^{68}$ Indeed, this practice arguably provides an indication of the greatest contribution ITLOS has thus far made to dispute settlement - that of providing a public record of the unilateral undertakings made by states during the course of settlement proceedings for the assumed purpose of holding states to those undertakings.

On the other hand, the assertion by ITLOS of such a low threshold of prima facie jurisdiction in these applications has been the subject of heavy criticism. The failure of ITLOS to closely delineate the parameters of the dispute before it prior to making a finding of prima facie

64 Straits of Johor, above n 63, para 48.

65 Straits of Johor, above n 63, para 68.

66 Straits of Johor, above n 63, paras 81-87 and 99.

67 Southern Bluefin Tuna (Provisional Measures), above n 52, para 44; Straits of Johor, above n 63, para 52.

68 Eastern Greenland (Norway v Denmark) [1933] PCIJ (Series A/B, no 53); Nuclear Tests (Australia and New Zealand v Japan) [1974] ICJ Rep 253. 
jurisdiction has been blamed for its apparently avaricious jurisdictional grab even in the face of competing treaty jurisdictions under which the disputes arguably more properly fell. ${ }^{69}$ The problem of treaty parallelism is dealt with more fully below, but it cannot go without note here.

Also criticised has been the merging by ITLOS of the requirement of "urgency" in article 290(5) with the requirements of article 290(1) regarding "appropriateness" to preserve the respective rights of the parties or prevent serious harm to the marine environment pending final decision. ${ }^{70}$ In this respect ITLOS is said to be distinguishing between the substantive rights relating to conservation and management of fish stocks or protection of the marine environment, and procedural rights relating to cooperation, information sharing, environmental impact assessment and consultation. In doing so, it is accused of ignoring the application of the precautionary principle to the question of urgency in the former case while denying the measures sought, but of apparently accepting the principle's application in the latter case and prescribing measures to protect these rights. ${ }^{71}$ But if there is no "urgency" to protect substantive rights, there can be no "urgency" to protect procedural rights which relate to the interpretation and application of those substantive rights. In this respect, it has been argued that ITLOS has "behaved less as a court of law and more as an agency of diplomacy"72 essentially concerned with breaking a diplomatic impasse and forcing the parties to return to the negotiating table. ${ }^{73}$

This question as to the role being played by the Part XV dispute settlement bodies has been thrown into stark relief by the decision of the Annex VII Arbitral Tribunal in the MOX Plant case to continue the ITLOS provisional measures, ${ }^{74}$ despite suspending proceedings in the case until

69 Kwiatkowska, above n 57, 33; "The Southern Bluefin Tuna Arbitral Award Did Get it Right: A Commentary and Reply to the Article by David A Colson and Dr Peggy Hoyle" (2003) 34 Ocean Dev and Int'l L 369, 381.

70 Survey for 1999, above n 49, 469-471; S Rosenne "The Case-Law of ITLOS (1997-2001): An Overview" in M H Nordquist and J N Moore (eds) Current Marine Environmental Issues and the International Tribunal for the Law of the Sea (2001); B Kwiatkowska "The Ireland v United Kingdom (MOX Plant) Case: Applying the Doctrine of Treaty Parallelism" 200318 Int'l J Marine and Coastal L1, 40 ["The MOX Plant Case"].

71 "The MOX Plant case", above n 70, 44-46.

72 Southern Bluefin Tuna (Provisional Measures), above n 52, Dissenting Opinion of Judge ad hoc Shearer, para 4; quoted again in MOX Plant (Provisional Measures), above n 58, Separate Opinion of Judge ad hoc Szérkely, para 21.

73 M Foster "The Mox Plant Case - Provisional Measures in the International Tribunal for the Law of the Sea" (2003) 16 Leiden Journal of International Law 611, 618-619; V Hallum "International Tribunal for the Law of the Sea: The Mox Nuclear Plant Case" (2002) 11 RECIEL 372, 374.

74 MOX Plant (Ireland v United Kingdom) (24 June 2003) Order 3 of the Arbitral Tribunal; and MOX Plant (Ireland $v$ United Kingdom) (14 November 2003) Order 4 of the Arbitral Tribunal (Arbitral Tribunal Constituted Pursuant to Article 287, and Article 1 of Annex VII, of the United Nations Convention on the Law of the Sea for the Dispute Concerning the MOX Plant, International Movements of Radioactive Materials, and the Protection of the Marine Environment of the Irish Sea). 
certain issues relating to European Community competence which will affect the tribunal's jurisdiction have been resolved by the European Court of Justice. The rationale for and import of this decision is discussed in more detail below. However, for present purposes it serves to note that the Annex VII Tribunal has maintained the view that its prima facie jurisdiction exists on the basis of the dispute arising under UNCLOS and, although rejecting the further particular measures sought by Ireland has, in addition to continuing the ITLOS order, called upon the parties to ensure that no action is taken by either of them which might aggravate or extend the dispute and to continue to report to the Tribunal the measures of cooperation taken. Nevertheless, while this may be a reflection of a difference of opinion as to the extent of the judicial function it does not, per se, provide evidence of substantive fragmentation.

\section{Other rules of international law}

A number of other substantive rules have been referred to in the Part XV jurisprudence. As already noted, ITLOS has had occasion to refer to the duty to cooperate in the conservation and management of marine living resources, the duty to prevent harm to the marine environment and the precautionary principle. While its decisions have not dealt with the substance of these principles ITLOS has at least reiterated the generally accepted view that "the conservation of the living resource of the sea is an element in the protection and preservation of the marine environment"75 and that the "duty to cooperate is a fundamental principle in the prevention of pollution of the marine environment under Part XII of UNCLOS and general international law". ${ }^{76}$ ITLOS has not directly invoked the precautionary principle but seems instead to have invoked its own "precautionary approach", ${ }^{77}$ requiring parties to act on the basis of "prudence and caution" in its provisional measures orders. Frustrating as this may be to those who would prefer judicial pronouncements on the scope and application of the principle, it is arguable that this may be appropriate given the preliminary nature of the proceedings in which these issues have been discussed to date. ${ }^{78}$

The apparently deliberate avoidance by ITLOS and the sole Annex VII tribunal to date of the invocation of certain legal principles, or the failure or refusal of ITLOS to address broader questions raised by the cases before it, may highlight tensions and uncertainties about the law. However, it does not provide evidence of substantive fragmentation. Nevertheless, given the

75 Southern Bluefin Tuna (Provisional Measures), above n 52, para 70.

76 MOX Plant (Provisional Measures), above n 58, para 82.

77 S Marr "The Southern Bluefin Tuna Cases: The Precautionary Approach and Conservation and Management of Fish Resources" (2000) 11 Euro J Int'l L 815.

78 See for example the comments of Judge Laing in his Separate Opinion in Southern Bluefin Tuna (Provisional Measures), above n 52, paras 12-21. See also M Tanaka "Lessons Learned from the Protracted MOX Plant Dispute: A Proposed Protocol on Marine Environmental Impact Assessment to the United Nations Convention on the Law of the Sea" (2004) 25 Mich J Int'l L 337, 382-384. 
multiple concurring, separate, and dissenting opinions which have often dealt with the interpretation of these principles in conflicting and ambiguous terms, a very real danger exists for multiple, inconsistent and tortured interpretations even within ITLOS should it ever have to decide another case on its merits.

This danger is perhaps evidenced by the decisions of ITLOS in the MV Saiga case. In the prompt release proceedings in MV Saiga (No1) the Tribunal accepted that: ${ }^{79}$

Laws or regulations on bunkering of fishing vessels may arguably be classified as laws or regulations on activities within the scope of the exercise by the coastal state of its sovereign rights to explore, exploit, conserve and manage the living resources in the exclusive economic zone.

However, when the case was heard on its merits, ITLOS refused to address the issue of whether offshore bunkering was a legitimate activity in the EEZ. Instead, it held that attempts to regulate bunkering of fishing vessels in the EEZ through the extension of customs laws were inconsistent with UNCLOS and Guinea was therefore in breach of the convention. ${ }^{80}$ While this may be consistent with the letter of UNCLOS and the logical result of Guinea's characterisation of the legislation in question, the decision completely ignores significant state practice which regulates bunkering in the EEZ as a condition of fishery access.

As between ITLOS and other tribunals the danger of substantive fragmentation remains, in theory. However, ITLOS jurisprudence relating to nationality of claims and nationality of ships provides some cause for optimism. In MV Saiga (No 2) ITLOS confirmed the generally accepted view that for the purposes of UNCLOS and of international law in general a "ship [is] a unit, as regards the obligations of the flag State with respect to the ship and the right of a flag State to seek reparation for loss or damage caused to the ship by acts of other States and to institute "prompt release proceedings". ${ }^{81}$ In this respect, a "ship, everything on it, and every person involved or interested in its operations are treated as an entity linked to the flag State. The nationalities of these persons are not relevant". ${ }^{82}$ Thus, it is for the flag state to exercise its rights of diplomatic protection in respect of its ships regardless of the nationalities of any other persons involved with the life of the ship.

This then begs the question of how to determine the identity of the flag state. In the MV Saiga (No 2) ITLOS held that for the purposes of article 91 of UNCLOS registration in accordance with domestic legislation is prima facie evidence of nationality and that "the nationality of a ship is a question of fact to be determined, like other facts in dispute before it, on the basis of evidence

79 MV Saiga (No 1), above n 24, para 63.

81 MV Saiga (No 2), above n 31, para 106.

82 MV Saiga (No 2), above n 31, para 106. 
adduced by the parties". ${ }^{83}$ Moreover, ITLOS confirmed that the existence of a genuine link was not a condition of recognition of nationality. Rather, the genuine link requirement was simply there to secure more effective implementation of flag state responsibilities, however and wherever defined and delineated. ${ }^{84}$ This statement of principle was followed in the Grand Prince case where, on the evidence, ITLOS found the applicant state did not fulfill the evidentiary requirements for standing before the Tribunal as a flag state as, at the time of application to ITLOS, the vessel concerned had either been deregistered or its provisional patent of registration had expired. ${ }^{85}$ Whatever one thinks of the appreciation by ITLOS of the conflicting evidence before it in the Grand Prince case, ${ }^{86}$ it appears that its interpretation of the requirements of registration and genuine link is consistent with the understanding underlying adoption of the provisions in UNCLOS. ${ }^{87}$ The interpretation also appears consistent with subsequent state practice which has sought to delineate the parameters of flag state responsibilities, not through development or extension of the criteria of the genuine link, but rather through the specific elaboration of these responsibilities in international agreements such as the United Nations Food and Agriculture Organisation Compliance Agreement, ${ }^{88}$ and the United Nations Fish Stocks Agreement. Thus, it appears that, in large part, fears of substantive fragmentation in the law of the sea have not yet materialised.

\section{B Part XV and Procedural Fragmentation}

Perhaps the greater challenge to the future of compulsory dispute settlement under UNCLOS comes from the problem of procedural fragmentation. While related to substantive fragmentation, the problem here is not one of inconsistency in the interpretation and application of legal rules, but of competing jurisdictions and the availability of an appropriate forum in which those rules can be interpreted and applied. Procedural fragmentation can arise in three ways. First, permissible declarations may place a vast array of disputes beyond the reach of the compulsory settlement provisions. Second, different specialist bodies of law, or "self contained regimes" may provide for inconsistent but equally compulsory dispute settlement procedures applying possibly conflicting bodies of law. Finally, the invocation of what have come to be referred to as "parallel treaties" may also remove disputes entirely from the Part XV regime.

83 MV Saiga (No 2), above n 31, para 66

MV Saiga (No 2), above n 31, paras 65-66 and 83-86.

5 Grand Prince (Belize v France) 125 ILR 251 (ITLOS).

V Lowe "The International Tribunal for the Law of the Sea: Survey for 2001" (2002) 17 Int'l J Marine and Coastal L 463, 473-476 [Survey for 2001]. 


\section{Declarations avoiding jurisdiction}

Obviously, states not party to UNCLOS cannot be bound by the compulsory dispute settlement procedures in Part XV. Thus, the Canada/Spain fisheries dispute could only go to the ICJ under that Court's contentious jurisdiction. Canada had, however, filed a reservation to the ICJ's jurisdiction in respect of the type of dispute in issue. The ICJ therefore lacked jurisdiction to hear the case ${ }^{89}$ Perhaps most notably, the United States is still not a party to UNCLOS. Disputes arising, for example, from United States interdiction activities pursuant to the Proliferation Security Initiative which may interfere with the freedom of navigation can therefore not be subject to UNCLOS's compulsory procedures. ${ }^{90}$

However, as noted above, even parties to UNCLOS can file declarations exempting a vast range of disputes from the compulsory settlement provisions. For example, while Canada is now party to UNCLOS, in its declaration made upon ratification Canada exempts from the compulsory provisions disputes relating, inter alia, to its law enforcement activities in regard to the exercise of its sovereign rights or jurisdiction in respect of its EEZ fisheries. ${ }^{91}$ It will be recalled that disputes relating to EEZ fisheries and marine scientific research are automatically excluded from compulsory procedures. The United Nations Fish Stocks Agreement, to which Canada is also a party, maintains this limitation. ${ }^{92}$ Thus, it is not immediately clear that the resolution of the Canada/Spain dispute would be any different under Part XV given that Canada alleged it was enforcing its domestic legislation enacted in the exercise of its sovereign rights or jurisdiction in the EEZ.

Australia, too, has taken the self-serving step of filing a declaration exempting disputes relating to the delimitation of the territorial sea, EEZ and continental shelf from the compulsory procedures. ${ }^{93}$ It has also filed a reservation exempting these disputes from the ICJ's contentious jurisdiction. ${ }^{94}$ Australia's purpose in doing so was to ensure no access by East Timor to any

89 Fisheries Jurisdiction (Spain v Canada) [1995] ICJ Rep 87.

90 See "Proliferation Security Initiative" <http://usinfo.state.gov> (last accessed 8 November 2005).

91 Government of Canada "Declaration Made Upon Ratification [of UNCLOS]" (7 November 2003).

92 Fish Stocks Agreement, above n 47, art 32.

93 Government of Australia "Declaration under paragraph 1 of Article 287 of the 1982 United Nations Convention on the Law of the Sea" (21 March 2002).

94 Government of Australia "Declaration under paragraph 2 of Article 36 of the Statute of the International Court of Justice" (21 March 2002). 
contentious or compulsory mechanism for the determination of its maritime boundaries with Australia. ${ }^{95}$

The first difficulty for the Part XV regime is, therefore, that it is neither as comprehensive nor as compulsory as its proponents suggest. While this point has been made by many, one commentator has succinctly noted that describing UNCLOS provisions as providing for compulsory third party settlement with some exceptions is "little different from saying that the ICJ has compulsory jurisdiction - as long as all states accept the optional clause". ${ }^{96}$ In other words, the provisions themselves have led to greater procedural fragmentation into compulsory and consensual forms of jurisdiction. ${ }^{97}$

\section{The problem of self contained regimes}

The possible clash of interpretations under two specialist regimes also provides cause for concern, although to date the consequences of such a clash have not yet been made manifest. The potential for difficulty was, however, demonstrated in the Swordfish dispute between the European Community (EC) and Chile which arose out of the unilateral extension by Chile of the application of its swordfish conservation measures to the high seas. EC vessels fishing in contravention of those measures were prohibited from landing their catches in Chilean ports. After a lengthy history of disputation, 98 in April 2000 the EC requested formal consultations under the WTO Understanding on Rules and Procedures Governing the Settlement of Disputes. ${ }^{99}$ Consultations took place in June 2000 but the matter was not resolved.

In July 2000 the EC agreed to a request from Chile for submission of the dispute to an Annex VII tribunal although in November 2000 the parties agreed, instead, to submit it to a special chamber of ITLOS. At issue was whether the Chilean legislation and its implementation violated the rights of EC vessels to fish on the high seas. ${ }^{100}$ In the meantime, in November 2000, the EC

95 G Triggs and D Bialek "Australia Withdraws Maritime Disputes from the Compulsory Jurisdiction of the International Court of Justice and the International Tribunal for the Law of the Sea" (2002) 17 Int'l J Coastal and Marine L 423.

96 S Scott "The Contribution of the LOS Organisations to its Harmonious Implementation" in Elferink and Rothwell, above n 46, 318.

97 As predicted by Boyle in 1997. See A Boyle "Dispute Settlement and the Law of the Sea Convention: Problems of Fragmentation and Jurisdiction" (1997) 46 ICLQ 37, 47.

98 For detailed discussion of the dispute see M Orellana "The Swordfish Dispute between the EU and Chile at the ITLOS and the WTO" (2002) 71 Nordic Journal of International Law 55; R Rayfuse Non-Flag State Enforcement in High Seas Fisheries (Martinus Nijhoff, Leiden, 2004) 315-323.

99 Chile - Measures Affecting the Transit and Importation of Swordfish-Request for Consultations by the European Communities (26 April 2000) WT/DS193/1.

100 Case Concerning the Conservation and Sustainable Exploitation of Swordfish Stocks in the South-Eastern Pacific Ocean (Chile v European Community) (20 December 2000) Order regarding Constitution of Chamber. 
requested the establishment of a WTO panel to determine whether the Chilean bans on landings and transshipments violated the General Agreement on Tariffs and Trade 1994 by causing a loss of competitiveness and consequent damage to the EC industry and causing adverse trade effects to EC exporters. ${ }^{101}$

What these two very different tribunals would have made of these cases remains a matter for speculation as both cases were suspended following agreement between the parties on a Provisional Agreement intended to provide a framework for a process leading to final agreement, although the parties reserved the right to revive the proceedings at any time. ${ }^{102}$ Nevertheless the potential for serious substantive fragmentation as a result of this procedural fragmentation, should such cases proceed in future, cannot be ignored.

\section{The problem of parallel treaties}

Even apart from the difficulties noted above, a more troubling threat to compulsory dispute settlement under UNCLOS has arisen from UNCLOS bodies' own jurisprudence in the context of the interpretation and application of parallel treaties, as vividly demonstrated in the Southern Bluefin Tuna (Jurisdiction and Admissibility), and MOX Plant cases.

In the Southern Bluefin Tuna case, it will be recalled that ITLOS granted provisional measures on the basis that the Annex VII Tribunal would, prima facie, have jurisdiction over the case. ITLOS considered that the mere fact that the dispute fell under the 1993 CCSBT did not exclude the dispute also arising under the provisions of UNCLOS in regard to the conservation and management of highly migratory species and the parties were therefore at liberty to invoke UNCLOS provisions for the purpose of resolving that dispute. ${ }^{103}$ The Annex VII Tribunal, however, reached quite the opposite conclusion. Although recognising that "it is a commonplace of international law and state practice for more than one treaty to bear upon a particular dispute" and that "the conclusion of an implementing convention does not necessarily vacate the obligations imposed by the framework convention upon the parties to the implementing convention", ${ }^{104}$ and

101 Chile - Measures Affecting the Transit and Importation of Swordfish - Request for the Establishment of a Panel by the European Communities (7 November 2000) WT/DS193/2; General Agreement of Tariffs and Trade (15 April 1994) 1867 UNTS 187.

102 The text of the Provisional Agreement is incorporated into: Chile - Measures Affecting the Transit and Importation of Swordfish - Agreement between the European Communities and Chile - Communication for the European Communities (6 April 2001) WT/DS193/3; (9 April 2001) WT/DS193.Add.1. This suspended the WTO proceedings. The ITLOS proceedings were also suspended: Case Concerning the Conservation and Sustainable Exploitation of Swordfish Stocks in the South-Eastern Pacific Ocean (Chile v European Community) (15 March 2001) Order of ITLOS.

103 Southern Bluefin Tuna (Provisional Measures), above n 52, para 51.

104 Southern Bluefin Tuna (New Zealand v Japan, Australia v Japan) (Jurisdiction and Admissability) (4 August 2000) Award of the Arbitral Tribunal, para 52. 
that the dispute in the case arose under both the CCSBT and UNCLOS, the Annex VII Tribunal held that the dispute was, in fact, a single dispute under both conventions and that the dispute settlement provisions of the CCSBT precluded reference to those in UNCLOS. ${ }^{105}$ The Annex VII Tribunal specifically stated that the LOSC "falls significantly short of establishing a truly comprehensive regime of compulsory jurisdiction entailing binding decisions", ${ }^{106}$ and was wholly untroubled by the consequence that disputes arising under parallel treaties negotiated both before and after UNCLOS could be excluded from the operation of Part XV compulsory procedures. To hold otherwise, it said "would be effectively to deprive of substantial effect the dispute settlement provisions of those implementing agreements which prescribe dispute resolution by means of the parties' choice". ${ }^{107}$

In his separate opinion, Sir Kenneth Keith considered this result to be the abnegation of the very object and purpose of UNCLOS, based, as it was, on the shared understanding of the critical centrality of the compulsory dispute settlement provisions. ${ }^{108}$ In his opinion, absent an expressly worded exclusion of UNCLOS provisions in the CCSBT no such exclusion should be implied. Commentators, too, have criticised the award noting that it effectively makes Part XV of UNCLOS subordinate to subsequent regional agreements and removes from UNCLOS procedures any case raising issues under both UNCLOS and another agreement in which the dispute is centered. ${ }^{109}$

Similar issues have also arisen in the MOX Plant case. Again, it will be recalled that ITLOS granted provisional measures in the case on the basis of its assessment that the Annex VII Tribunal would, prima facie, have jurisdiction. Apparently undeterred by the reasoning of the Annex VII Tribunal in the Southern Bluefin Tuna (Jurisdiction and Admissibility) award, ITLOS followed its own reasoning in the Southern Bluefin Tuna (Provisional Measures) order, recognising that the dispute fell under both UNCLOS and the Convention for the Protection of the Marine Environment of the North-East Atlantic (OSPAR) ${ }^{110}$ EURATOM and European Union treaties, but that those

105 Southern Bluefin Tuna (Jurisdiction and Admissability), above n 104, paras 54-59.

106 Southern Bluefin Tuna (Jurisdiction and Admissability), above n 104, para 62.

107 Southern Bluefin Tuna (Jurisdiction and Admissability), above n 104, para 63.

108 Separate Opinion of Justice Sir Kenneth Keith, para 23.

109 A Boyle "The Southern Bluefin Tuna Arbitration" (2001) 50 ICLQ 447, 451; C Romano "The Southern Bluefin Tuna Dispute: Hints of a World to Come ... Like it or Not" (2001) 32 Ocean Dev and Int'l L 313; D Colson and P Hoyle "Satisfying the Procedural Prerequisites to the Compulsory Dispute Settlement Mechanisms of the 1982 Law of the Sea Convention: Did the Southern Bluefin Tuna Tribunal Get it Right?" (2003) 34 Ocean Dev and Int'l L 59; L Sturtz "Southern Bluefin Tuna Case: Australia and New Zealand v Japan" (2001) 28 Ecology LQ 455; J Peel "A Paper Tiger which Dissolves in the Rain? The Future for Resolving Fisheries Disputes under UNCLOS in the Aftermath of the Southern Bluefin Tuna Arbitration" (2002) 3 MJIL 53.

110 Convention for the Protection of the Marine Environment of the North-East Atlantic (22 September 1992) 32 ILM 1069. 
other disputes had a separate existence from the one under UNCLOS. Accordingly, UNCLOS dispute could be brought under the Part XV procedures. ${ }^{111}$

This time, however, the Annex VII Tribunal in the MOX Plant case has been less hasty to absolutely relinquish its jurisdiction. Instead, it has continued to assert its prima facie jurisdiction over any aspects of the dispute which fall under UNCLOS and not under the other treaties. In this respect the Annex VII Tribunal has expressly stated that in its view the OSPAR Convention does not substantially cover the field of the dispute so as to take it outside UNCLOS. ${ }^{112}$ In other words, there is no unity of dispute as was found by the Annex VII Tribunal Southern Bluefin Tuna (Jurisdiction and Admissibility) award. However, the MOX Plant Annex VII Tribunal has suspended further proceedings in the case pending the resolution of proceedings in the European Court of Justice in relation to the jurisdictional competencies of the European Community and the EC member states. As the Tribunal notes, the determination of its jurisdiction, "and the identification of the treaty provisions and other rules of international law which the Tribunal could apply to the dispute brought before it by Ireland, are crucially dependent upon the resolution of" these problems. ${ }^{113}$ The Tribunal appears to accept this is a preliminary step to be taken before deciding the issue of jurisdiction and is wholly unrelated to that issue. ${ }^{114}$

Whether, and if so in what manner, this dispute will ever return to the Annex VII Tribunal remains to be seen. Admittedly this is the result of a special situation relating to the jurisdictional competences of the EC and its member states. However, even putting that issue aside, the case raises larger questions as to the interplay of other parallel treaties relating to aspects of the dispute. Ultimately, particularly if proceedings progress under the other treaty regimes first (as indeed, they have in respect of the OSPAR Convention claim), ${ }^{115}$ the jurisdiction and freedom of decisional capacity of the Annex VII Tribunal may be so circumscribed by the interpretation or application of the other parallel treaties as to be meaningless.

Quite apart from concerns with the substantive content and effect of the decisions in the Southern Bluefin Tuna and Mox Plant cases, these cases raise serious questions relating to procedural fragmentation as a result of the various conflicting and overlapping dispute settlement

111 MOX Plant (Provisional Measures), above n 58, paras 48-52.

112 MOX Plant (Jurisdiction and Merits) (24 June 2003) Order No 3 (Suspension of Proceedings on Jurisdiction and Merits, and Request for Further Provisional Measures), 24 June 2003 at paras 15-19.

113 MOX Plan (Jurisdiction and Merits), above n 112, para 23.

114 R Churchill and J Scott "The Mox Plant Litigation: The First Half-Life" (2004) 53 ICLQ 643, 660.

115 Dispute Concerning Access to Information under Article 9 of the OSPAR Convention (Ireland v UK), (2 July 2003) Final Award. See M Fitzmaurice "Dispute Concerning Access to Information Under Article 9 of the OSPAR Convention (Ireland v United Kingdom and Northern Ireland) (2003) 18 Int'l J Marine and Coastal 541 
mechanisms involved. The difficulty for UNCLOS regime is manifest when it is realised that well over one hundred bilateral and multilateral treaties can be seen as implementing agreements or parallel treaties to UNCLOS, many of which have their own dispute settlement clauses. ${ }^{116}$ Indeed, the problem may not lie in the dangers of forum shopping and inconsistent decisions but, rather, in the very real possibility that, given both the existence of possibly conflicting procedures and the significant hurdles to be overcome in bringing a case within UNCLOS compulsory dispute procedure, no tribunal will have compulsory jurisdiction over a dispute or any suitably justiciable part thereof. ${ }^{117}$ In other words, as Boyle predicted, this procedural fragmentation appears to leave an "empty shell which can be filled only if the parties agree on consensual submission of the dispute to whatever forum they choose". 118

\section{IMPLICATIONS FOR THE FUTURE OF COMPULSORY DISPUTE SETTLEMENT UNDER UNCLOS}

Turning to the implications that can be drawn from this jurisprudence for the future of the UNCLOS compulsory dispute settlement regime, perhaps the central question to be answered is whether, and if so in what manner, that regime has thus far contributed to the settlement of disputes concerning the law of the sea. This question has both quantitative and qualitative aspects.

A quantitative analysis requires a simple inquiry into the number of cases which have been brought pursuant to Part $\mathrm{XV}$ and in which resolution has occurred. In six prompt release applications ITLOS has resolved four and declined jurisdiction in one. The sixth was settled before the Tribunal heard the case. ${ }^{119}$ Certainly, the effect of article 292 has been to provide a forum in which these disputes can and have been resolved. Moreover, in doing so, ITLOS has exercised its jurisdiction in what is generally regarded as an expeditious and effective manner. However, it bears noting that this is a rather modest number of cases. More importantly, it is not at all clear whether the number of prompt release cases will continue to grow. Indeed, as the Tribunal refines the criteria for, and parameters of, reasonableness of bond it is likely that the number of prompt release applications will drop.

The provisional measures jurisdiction under article 290 appears to have led to rather more mixed results. In none of the cases decided by ITLOS to date has it prescribed the provisional

116 B Kwiatkowska "The Australia and New Zealand v Japan Southern Bluefin Tuna (Jurisdiction and Admissibility) Award of the First Law of the Sea Convention Annex VII Arbitral Tribunal" (2001) 16 Int'l J Marine and Coastal L 239, 286-289; and B Kwiatkowska "The Southern Bluefin Tuna Award (Jurisdiction and Admissibility)" in Ando and others, above n 21, 723-727.

117 Colson and Hoyle, above n 109, 63.

118 Boyle, above n 97, 47.

119 Chaisiri Reefer 2 (Panama v Yemen) (13 July 2001) Order of ITLOS discontinuing the proceedings and removing the case for the Tribunal's list of cases. 
measures sought. Nevertheless, it has prescribed measures in each case, substituting its own appreciation of what is needed and essentially ordering cooperation between the parties pending a determination on the merits. However, in only one of these cases, the MV Saiga (No 2), has the dispute actually proceeded to a hearing on the merits. While the Straits of Johor case is still pending, the Southern Bluefin Tuna case was dismissed for want of jurisdiction and the MOX Plant case has been suspended pending determination of EC law issues. It has been argued that the merits phases of these cases have been rendered unnecessary by the prescription of effective provisional measures essentially forcing the parties back to the negotiating table. ${ }^{120}$ This may be true. However, while the result of the provisional measures proceedings may have played a role in overcoming negotiating impasses, the proceedings have not provided the actual resolution of the dispute. From a purely institutional, quantitative viewpoint, it is irrelevant that the parties may have subsequently reached some form of resolution of the issues themselves.

It is true that at least two cases are currently being submitted to Annex VII tribunals: the Straits of Johor case and a maritime boundary delimitation case between Guyana and Suriname. ${ }^{121}$ It is also acknowledged that these are early days for Part XV and it can therefore not be expected that a large number of cases will have arisen. However, at least to the present, quantitatively speaking, there has been little contribution by the Part XV compulsory dispute settlement regime in terms of actually rendering judicial determinations of legal issues to settle disputes between states, except in the very specific area of prompt release cases brought before ITLOS.

Rather more complex, but arguably more disappointing, is the qualitative contribution of the Part XV compulsory regime to the settlement of disputes and to the development of the law of the sea and international law in general. For example, the result of the Southern Bluefin Tuna (Jurisdiction and Admissibility) award has simply been to place a vast range of disputes outside the Part XV regime. As noted above, more than one hundred parallel treaties exclude the operation of the regime on the Southern Bluefin Tuna analysis, over and above those which specifically exclude the operation of Part XV. Narrow readings of the decision and its reliance on "implicit" exclusion may ameliorate this result. However, this remains to be seen.

Likewise, the prompt release cases have certainly resulted in the resolution of the immediate release issue and the delineation of the criteria for a reasonable bond. However, these decisions, which have been heavily criticised for failing to take sufficient account of non-economic values such as the conservation of living resources and the effective enforcement of national fisheries

120 B Mansfield "The Southern Bluefin Tuna Arbitration: Comments on Professor Barbara Kwiatkowska's Article" (2000) 15 Int'l J Marine and Coastal L 361; and B Mansfield "Compulsory Dispute Settlement After the Southern Bluefin Tuna Award" in Elferink and Rothwell, above n 46.

121 T Donovan "Guyana Invokes Annex VII of United Nations Convention on Law of the Sea Against Suriname for Disputed Maritime Boundary" (April 2004) ASIL Insights Washington DC. 
laws and regulations, ${ }^{122}$ have merely led to attempts to reformulate and relocate the dispute as to coastal state competence in the fight against IUU fishing as evidenced, for example, by Australian efforts in the Commission on the Conservation of Antarctic Marine Living Resources to amend the operation of article 73 as between Commission members and Australia's attempts to have Patagonian toothfish listed as endangered under the Convention on the Trade in Endangered Species. ${ }^{123}$

The qualitative contribution of the provisional measures decisions is also questionable. Admittedly, by nature these proceedings are preliminary, incidental, and are not of themselves necessarily intended to resolve disputes. Nevertheless, they are said to have contributed in many ways to a better understanding or appreciation, by the parties, of the disputes in question and to even have encouraged cooperation between the parties in order to achieve a mutually acceptable outcome. In particular, the generous assumption by ITLOS of prima facie jurisdiction and its granting of measures calling for cooperation, as well as its public recording of unilateral undertakings and commitments to consult and cooperate is praised as having had a salutary effect on the parties to the disputes. ${ }^{124}$

However, the outcome in the Southern Bluefin Tuna case was not a "judicial" outcome, or even one achieved on the basis of the application of the law or the rule of law. Rather, it was based on political expediency, achieved by sidestepping the legal dispute entirely. ${ }^{125}$ It may be true that cooperation between Japan and Australia and New Zealand improved in the Commission during and after the Southern Bluefin Tuna proceedings but in large part this was achieved merely by shifting the locus of their concern to other states fishing in the region. Members of the Commission continue to argue about conservation status, quota level and allocation. Indeed, they are now arguing over whether, because of the depleted status of the stocks, the original management objective of the convention can be achieved at all. ${ }^{126}$

122 See the Dissenting Opinion of Judge Anderson in the Camuoco case, above n 27; see also: Survey for 2000, above n 29; D Rothwell "Building on the Strengths and Addressing the Challenges: The Role of the Law of the Sea Institutions" (2004) 35 Ocean Dev and Int'l L 131.

123 For a discussion see A Serdy and M Bliss "Prompt Release of Fishing Vessels: State Practice in Light of the Cases Before the International Tribunal for the Law of the Sea" in Elferink and Rothwell, above $n 46$. Convention on the Trade in Endangered Species of Wild Flora and Fauna (3 March 1973) 993 UNTS 243.

124 Mansfield, above n 120; Kwiatkowska, above n 116.

125 Romano, above n 109, 334-336; T Stephens "The Limits of International Adjudication in International Environmental Law: Another Perspective on the Southern Bluefin Tuna Case" (2004) 19 Int'l J Marine and Coastal L 177, 183-186.

126 Report of the Extended Commission of the Tenth Annual Meeting of the Commission for the Conservation of Southern Bluefin Tuna (CCSBT, Canberra, 2003) paras 37-48. 
In the Swordfish case, too, political expediency dictated the outcome with Chile's desire for a free trade agreement with the EC overriding its desire to ensure the conservation status of the Eastern Pacific swordfish. The Provisional Agreement which purported to settle the dispute has been heavily criticised as not being capable of ensuring effective conservation status and has, in any event, yet to be fully implemented. ${ }^{127}$

In short, apart from the limited contributions of ITLOS to the law relating to prompt release and the nationality of ships, the most significant qualitative contribution of the Part XV regime to date appears to have been in providing a modus operandi for institutionalised compulsion and supervision of political negotiations, rather than a judicial dispute settlement mechanism deciding disputes in accordance with international law. Indeed, far from developing the "law habit", ${ }^{128}$ at best what has developed to date can only be described as a "litigation habit" by which states utilise the Part XV procedures, in particular the provisional measures procedures, to attempt to influence their negotiations with other states. That a litigation habit should develop to promote the pursuit of peaceful relations amongst states is undoubtedly to be welcomed. However, this essentially political process should not be confused with a system of compulsory dispute settlement on the basis of international law.

As admitted at the outset, it is still early days for UNCLOS and its compulsory dispute settlement provisions. However, if the past is prologue, the future does not look overly bright, either for the procedures and institutions thereby established or for the development of the law of the sea through the invocation of this regime. The most likely implications in the short, or even medium, term are that states will continue to find creative ways to ensure that disputes do not fall under the Part XV compulsory settlement regime and that, given the very limited number of states which have accepted the jurisdiction of ITLOS under article $287,{ }^{129}$ ITLOS will continue to be used merely to decide limited numbers of prompt release cases and provisional measures applications pending establishment of Annex VII Tribunals. Assuming ITLOS continues to take a wide approach to the question of prima facie jurisdiction, its docket may continue to grow. However, as Annex VII and other tribunals provide more guidance as to their own jurisdiction, the ability of ITLOS to find prima facie jurisdiction for the purpose of ordering provisional measures, the implementation of which it would supervise, will undoubtedly decline. ITLOS may yet become

127 Orellana, above n 98, 69; see also European Union "The EU encourages a multilateral arrangement for the management of South-East Pacific swordfish" (16 July 2002) Press Release.

128 Or, as Kwiatkowska calls it, a "judicial habit": Kwiatkowska, above n 116, 291.

129 As at 18 November 2003 only 16 states had accepted the jurisdiction of ITLOS as their first preference in their article 287 declarations. See the declarations and statements available in the law of the sea section of the United Nations website <http://www.un.org $>$ (last accessed 8 November 2005). As Lowe notes, the geographical distribution of these states makes it extremely unlikely a dispute will ever arise between two who have accepted the ITLOS jurisdiction: see R Churchill and V Lowe "The International Tribunal for the Law of the Sea: Survey for 2002" (2003) 18 Int'l J Marine and Coastal L 447, 456. 
the white elephant its critics initially accused it of being. Additionally, given the difficulties posed by procedural fragmentation it is unlikely that many cases will be heard on the merits. The content of the law of the sea will thus continue to be a matter of debate and uncertainty subject to the vagaries of power politics and conflicting state practice.

A long term prognosis based on the scant practice to date would be unwise. It does seem fair to say that the compulsory dispute settlement provisions are never likely to provide judicial settlements or development of the law in disputes raising environmental issues under UNCLOS. ${ }^{130}$ However, rather than allow the machinery to fall into desuetude, it is possible that states will seek to make greater use of ITLOS and Annex VII tribunals for the purpose of resolving disputes relating to the freedom of navigation or upon issues regarding which there is little dispute as to the applicable law. The initiation of Annex VIII tribunals for the resolution of purely technical disputes may also emerge. Moreover, while the issue has not been canvassed in this paper, at least in respect of the role of ITLOS, it must be noted that with the coming into operation of the Part XI regime relating to deep seabed mining, the Seabed Disputes Chamber may prove to be the most effective and most enduring aspect of the Part XV compulsory dispute settlement regime. All of this, however, remains to be seen.

\section{CONCLUSION - THE FUTURE OF COMPULSORY DISPUTE SETTLEMENT UNDER UNCLOS}

This article has reviewed the jurisprudence which has emerged pursuant to the Part XV compulsory dispute settlement provisions in an attempt to provide a tentative prognosis as to the future of compulsory dispute settlement under UNCLOS. In so doing it has examined whether the fears of fragmentation have proved justified. It has been demonstrated that the feared substantive fragmentation in the sense of inconsistent interpretations or applications of legal rules has not yet materialised. Rather more fundamental, however, has been the problem of determining the jurisdictional reach of the compulsory dispute settlement provisions in light of the procedural fragmentation caused by a plethora of conflicting and overlapping jurisdictions (or exclusions thereof) under jurisdictional declarations, parallel treaties and other specialist bodies of international law.

Even accepting that UNCLOS compulsory dispute settlement regime was never intended to be comprehensive, it has proved to be even more circumscribed in scope than perhaps even its detractors imagined. The undoubtedly rather unfashionable and perhaps overly pessimistic conclusion to be drawn is that compulsory dispute settlement under UNCLOS for anything but the most technical and straightforward of disputes is not very bright. While implementation of these provisions will undoubtedly continue to contribute to the growth and vitality of the international

130 T Stephens "The Limits of International Adjudication in International Environmental Law: Another Perspective on the Southern Bluefin Tuna Case" (2004) 19 Int'l J Marine and Coastal L 177. 
legal profession, their contribution to the development of the law of the sea and international law in general seems likely to continue to be rather limited. 
